\title{
Physicochemical and Functional Properties of Dehydrated Japanese Quail (Coturnix japonica) Egg White
}

\author{
Maira Segura-Campos ${ }^{1}$, Roberto Pérez-Hernández ${ }^{2}$, Luis Chel-Guerrero ${ }^{1}$, Arturo Castellanos-Ruelas ${ }^{1}$, \\ Santiago Gallegos-Tintoré ${ }^{1}$, David Betancur-Ancona ${ }^{1^{*}}$ \\ ${ }^{1}$ Faculty of Chemical Engineering, Campus of Exact Sciences and Engineering, Autonomous University of Yucatán, Merida, Mexico; \\ ${ }^{2}$ Inalim Food Industry, Oaxaca, Mexico. \\ Email: ${ }^{*}$ bancona@uady.mx
}

Received February $7^{\text {th }}, 2013$; revised March $6^{\text {th }}, 2013$; accepted March $12^{\text {th }}, 2013$

\begin{abstract}
Physicochemical, functional and digestibility analyses were done of dehydrated quail egg white to determine its possible practical applications. Quail egg white was dehydrated by air convection using one of two temperatures and times: $\mathrm{M} 1\left(65^{\circ} \mathrm{C}, 3.5 \mathrm{~h}\right), \mathrm{M} 2\left(65^{\circ} \mathrm{C}, 5.0 \mathrm{~h}\right), \mathrm{M} 3\left(70^{\circ} \mathrm{C}, 3.5 \mathrm{~h}\right)$ and $\mathrm{M} 4\left(70^{\circ} \mathrm{C}, 5.0 \mathrm{~h}\right)$. Lyophilized quail egg white was used as a standard. All four air-dried treatments had good protein levels (92.56\% to 93.96\%), with electrophoresis showing the predominant proteins to be lysozyme, ovalbumin and ovotransferin. Denaturation temperatures ranged from $81.16^{\circ} \mathrm{C}$ to $83.85^{\circ} \mathrm{C}$ and denaturation enthalpy values from 5.51 to $9.08 \mathrm{~J} / \mathrm{g}$. Treatments M1-4 had lower water-holding $(0.90-2.95$ $\mathrm{g} / \mathrm{g})$ and oil-holding $(0.92-1.01 \mathrm{~g} / \mathrm{g})$ capacities than the lyophilized treatment $(4.5 \mathrm{~g} / \mathrm{g}, 1.95 \mathrm{~g} / \mathrm{g}$, respectively). Foaming capacity was $\mathrm{pH}$-dependent in all five treatments, with the lowest values at alkaline $\mathrm{pH}$ and the highest $(153 \%$ to $222 \%)$ at acid $\mathrm{pH}(\mathrm{pH} 2)$. Foam stability was lowest at acid $\mathrm{pH}$ and highest at alkaline $\mathrm{pH}$. Emulsifying activity in the air-dried treatments was highest at $\mathrm{pH} 8(41 \%-46 \%)$. Emulsion stability was pH-dependent and highest in $\mathrm{M} 3$ between $\mathrm{pH} 2$ and $4(96.16 \%$ to $95.74 \%$, respectively). In the air-dried treatments, in vitro protein digestibility was as high as $83.02 \%$ (M3).
\end{abstract}

Keywords: Coturnix japonica; Dehydrated Egg White; Physicochemical Properties; Functional Properties

\section{Introduction}

Japanese quail Coturnixjaponica belongs to the order Galliformes, family Phasidae, and is a separate species from the common quail Coturnixcoturnix Wild Japanese quail were first documented in the 8th Century [1] and had been domesticated as a pet song bird by around the 11th Century. The species has gained value as a food animal due to the unique flavor of its eggs and meat. Quail egg production is important in Japan and Southeast Asia, while quail meat is an element in many European cuisines. Its small body size $(80-300 \mathrm{~g})$ and consequent low maintenance cost, in addition to its short generation interval, disease resistance and high egg production make this species an excellent laboratory animal. Japanese quail is also the smallest avian species produced for meat and eggs, and has been extensively studied [2].

Although not yet accepted as a food source worldwide, quail is becoming increasingly important in various countries. In the Philippines, the rich taste of quail eggs has caused demand to surpass supply [3]. Quail products are

${ }^{*}$ Corresponding author. popular as conventional food in countries such as France, Italy, Greece, Japan and China, and interest is growing in them as a dietetic food rich in vitamins and minerals, particularly for children and the elderly [4]. In Mexico, quail egg demand is concentrated in Toluca, Valle de Bravo, Temascaltepec and Tejupilco where it is mainly consumed in restaurants [5].

The high protein content of quail egg white makes it an excellent potential protein source for food industry applications. As with any protein source, its actual usefulness will depend on its functional properties, which affect food sensory characteristics and play an important role in the physical behavior of food and/or its ingredients during preparation, processing and storage. Many functional properties depend on exposure of hydrophobic groups on the molecular surface and the interactions of these groups with oil (emulsion), air (foam) or other protein molecules such as gels and coagula. Considering that hydrophobic amino acid residues are generally located inside globular protein molecules, unfolding of the native structure during processing steps such as homogenization, liquefaction or heating may be necessary to allow these 
hydrophobic groups to participate in intermolecular interactions. A protein's molecular flexibility can be constrained by the strength of hydrophobic and internal electrostatic interactions, which maintain the native structure, as well as by the presence of covalent disulphide intramolecular bonds [6].

Emulsification, foam formation and gelation, among other functional properties, are essential in food products such as desserts, puddings, reformulated meat products, tofu and surimi. The success of many cooked foods depends on protein coagulation, especially coagulation of egg proteins since when they coagulate they act as a structural bond with other ingredients. Foam contributes to the texture of bread, cakes, cookies, meringues, ice creams, and several bakery products, all of which require the incorporation of air to maintain texture and structure during and after processing. Air encapsulation and retention by proteins improves desirable textural attributes; this capacity to form and stabilize foam is related to proteins' amphiphilic behavior (polar/nonpolar) [6]. Chicken egg white has been used extensively in processed food because of its gelation and foam formation properties, and chicken egg ovalbumin proteins are common ingredientsin processed food. Quail egg white may also have potential applications as a food ingredient, depending on the required function in the final product. The present study objective was to characterize the physicochemical and functional properties of dehydrated Japanese quail (Coturnix japonica) egg white.

\section{Materials and Methods}

\subsection{Materials}

Japanese quail eggs were obtained from a commercial producer (Mexicapam Poultry Farm, San Martín Mexicapam, Oaxaca, Mexico). Reagents were analytical grade and purchased from J.T. Baker (Phillipsburg, NJ, USA), Sigma (Sigma Chemical Co., St. Louis, MO, USA), Merck (Darmstadt, Germany) and Bio-Rad (Bio-Rad Laboratories, Inc. Hercules, CA, USA).

\subsection{Dehydrated Egg White}

Egg white was isolated mechanically by foaming with a Moulinex blender and drying the foam in an air convection oven under four sets of conditions: $\mathrm{M} 1\left(65^{\circ} \mathrm{C}, 3.5 \mathrm{~h}\right)$; $\mathrm{M} 2\left(65^{\circ} \mathrm{C}, 5.0 \mathrm{~h}\right) ; \mathrm{M} 3\left(70^{\circ} \mathrm{C}, 3.5 \mathrm{~h}\right)$; and $\mathrm{M} 4\left(70^{\circ} \mathrm{C}, 5.0\right.$ h). As a control (ML), egg white was also freeze-dried (lyophilized) at $-47^{\circ} \mathrm{C}$ and $13 \times 10^{-3}$ mbar for $48 \mathrm{~h}$.

\subsection{Physicochemical Characterization}

\subsubsection{Proximate Composition}

Official AOAC procedures were used to determine nitrogen (method 954.01), fat (method 920.39), ash (method
923.03) and moisture (method 925.09) contents in the dehydrated quail egg white [7]. Nitrogen was determined with a Kjeltec System (Tecator, Sweden), protein calculated as nitrogen $\times 6.25$, and fat determined with a 4-h hexane extraction. Ash was calculated from sample weight after heating to $550^{\circ} \mathrm{C}$ for $2 \mathrm{~h}$. Moisture was measured based on sample weight loss after oven drying at $110^{\circ} \mathrm{C}$ for $4 \mathrm{~h}$.

\subsubsection{Electrophoresis}

Sodium dodecyl sulfate polyacrylamide gel electrophoresis (SDS-PAGE) was done as described by Schagger and von Jagow [8]. Briefly, 13\% acrylamide gels were prepared by mixing $2.6 \mathrm{~mL} 49.5 \%$ acrylamide-bisacrylamide ( $48 \%$ acrylamide and $1.5 \%$ bisacrylamide), $3.3 \mathrm{~mL}$ gel regulator (3 $\mathrm{M}$ Tris adjusted to $\mathrm{pH} 8.45$ and $0.3 \% 1$ ammonium persulphate and $0.3 \% \mathrm{SDS}), 1.03 \mathrm{~mL}$ glycerol, $2.8 \mathrm{~mL}$ distilled water, $50 \mu \mathrm{l}$ ammonium persulphate and $20 \mu \mathrm{l}$ TEMED. Running buffer composition was $0.1 \mathrm{M}$ Tris, $0.1 \mathrm{MTricine}$ (Sigma T-5816) and 0.1\% SDS for the cathode buffer, and 0.2 MTris (Sigma T$1503)$ at $\mathrm{pH} 8.9$ for the anode buffer. Samples were heated to $95^{\circ} \mathrm{C}$ for $2 \mathrm{~min}$ in $0.6 \mathrm{~mL} 0.1 \mathrm{M}$ Tris- $\mathrm{HCl}$ at $\mathrm{pH}$ 6.8, $5 \mathrm{~mL} 50 \%$ glycerol (w/v), $2 \mathrm{~mL} \mathrm{10 \%} \mathrm{SDS,} 1 \mathrm{~mL} \mathrm{1 \%}$ bromophenol blue (Sigma B-5525) (w/v) and $1.4 \mathrm{~mL}$ distilled water. Molecular weight standard (Bio-Rad) protein composition ranged from 20 to $111 \mathrm{kDa}$. Electrophoresis was run at a constant $20 \mathrm{~mA} / \mathrm{gel}$ voltage for $2 \mathrm{~h}$ before staining $(0.10 \%$ Coomassie blue G-250 in water: methanol: acetic acid 4:1:5 v/v/v for $1 \mathrm{~h}$ ). Destaining was done with a $10 \%(\mathrm{v} / \mathrm{v})$ acetic acid and $40 \%$ methanol solution for $12 \mathrm{~h}$.

\subsubsection{Temperature and Denaturalization Enthalpy}

Temperature and denaturalization enthalpy were determined with a DSC-7 (Perkin-Elmer Corp., Norwalk, CT) according to Martínez \& Añon [9]. Three milligrams (dry base - d.b.) of sample were placed in an aluminum pan, moisture level adjusted to $70 \%$ by adding de-ionized water, the pan hermetically sealed and left to equilibrate for $1 \mathrm{~h}$ at room temperature. It was then placed in the calorimeter and heated from $30^{\circ} \mathrm{C}$ to $130^{\circ} \mathrm{C}$ at a rate of $10^{\circ} \mathrm{C} / \mathrm{min}$, using an empty pan as reference.

\subsection{Functional Properties}

\subsubsection{Water-Holding (WHC) and Oil-Holding Capacity (OHC)}

These properties were determined by first weighing out 1 $\mathrm{g}$ sample and stirring it into $10 \mathrm{~mL}$ distilled water or corn oil (Mazola, CPI International) for one minute. These protein suspensions were then centrifuged at $2200 \mathrm{xg}$ for $30 \mathrm{~min}$, and supernatant volume measured. Water-holding capacity was expressed as $\mathrm{g}$ water held per g sample. 
Oil-holding capacity was expressed as g oil held per $\mathrm{g}$ protein sample [10].

\subsubsection{Foaming Capacity and Foam Stability}

Foam properties were evaluated over a $\mathrm{pH}$ range of 2 to 10. A $100 \mathrm{~mL}$ sample of $1.5 \%$ protein $(\mathrm{w} / \mathrm{v})$ suspension was blended at low speed in a Waring blender (Osterizer 10S-E) for $5 \mathrm{~min}$, and foam volume recorded after $30 \mathrm{~s}$. Foaming capacity was expressed as the percentage increase in foam volume measured at $30 \mathrm{~s}$. Foam stability was quantified by measuring residual foam volume 5, 30 and $120 \mathrm{~min}$ after blending. Both properties were determined as a function of $\mathrm{pH}[10]$.

\subsubsection{Emulsifying Activity (EA) and Emulsion Stability (ES)}

Emulsion properties were analyzed using $10 \mathrm{~mL}$ samples of a $2 \%(\mathrm{w} / \mathrm{v})$ suspension adjusted to $\mathrm{pH}$ values ranging from 2 to 10. These were homogenized using a Caframo RZ-1 homogenizer at $2000 \mathrm{rpm}$ for $2 \mathrm{~min}, 10 \mathrm{~mL}$ corn oil (Mazola, CPI International) added to each sample and the mixture homogenized for $1 \mathrm{~min}$. The emulsions were centrifuged in $15 \mathrm{~mL}$ graduated centrifuge tubes at 1200 $x g$ for $5 \mathrm{~min}$ and emulsion volume measured. Emulsifying activity was expressed as the percentage represented by the emulsified layer volume of the entire layer in the centrifuge tube. To determine emulsion stability, the emulsions were heated to $80^{\circ} \mathrm{C}$ for $30 \mathrm{~min}$, cooled to room temperature and centrifuged at $1200 \mathrm{xg}$ for $5 \mathrm{~min}$. Emulsion stability was expressed as the percentage represented by the remaining emulsified layer volume of the original emulsion volume [10].

\subsection{In Vitro Protein Digestibility}

Following Hsu et al. [11], a multienzyme system consisting of porcine pancreatic trypsin type IX, bovine pancreatic chymotrypsin type II, and porcine intestinal peptidase grade III (Sigma Chemical Co, St. Louis, MO, USA) was selected. A total volume of $50 \mathrm{~mL}$ of an aqueous protein suspension $(6.25 \mathrm{mg} / \mathrm{mL})$ was prepared by mixing the sample with distilled water, adjusting $\mathrm{pH}$ to 8.0 , and stirring in a water bath at $37^{\circ} \mathrm{C}$. The multienzyme solution was maintained in an ice bath and adjusted to $\mathrm{pH}$ 8.0. While stirring, a $5 \mathrm{~mL}$ aliquot of multienzyme solution was added to the protein suspension at $37^{\circ} \mathrm{C}$. A rapid decline in $\mathrm{pH}$ occurred which was recorded over a 10 min period using a $\mathrm{pH}$ meter. In vitro protein digestibility was calculated with the equation $\mathrm{PD}=210.46-$ 18.10 ( $\mathrm{pH}$ after $10 \mathrm{~min}$ ).

\subsection{Statistical Analysis}

All results were analyzed using descriptive statistics with a central tendency and dispersion measures. Data were analyzed using a one-way analysis of variance (ANOVA) and a Duncan's multiple range test; all calculations were done in triplicate. All analyses were done according to Montgomery [12] and processed using the Statgraphics Plus version 5.1 software.

\section{Results and Discussion}

\subsection{Proximate Composition}

Proximate analyses showed moisture content of the dehydrated quail egg white to range from 6.16 (M2) to 7.42 (M3) (Table 1). Initial moisture content in quail albumen is reported to be $87.82 \%$ (Dudusola, 2010), meaning a substantial loss of moisture occurred. Ash content ranged from $5.96 \%(\mathrm{M} 2)$ to $7.08 \%(\mathrm{M} 4)$, which are higher than reported for quail $(1.00 \%)$ and guinea fowl $(0.79 \%)$ albumen [13]. This relatively high ash content suggests that dehydrated quail egg white is a good source of minerals. Protein content ranged from $92.56 \%$ (M4) to $93.96 \%$ (M1). These values are higher than the $80.72 \%$ [14] and 90\% [15] reported for aspersion-dried chicken egg, the $80 \%$ reported for dehydrated chicken egg white [16], and the $83.9 \%$ reported for quail albumen [13]. The protein content observed here in dehydrated quail egg white was also higher than protein content in young (18.99\%) and spent (17.48\%) quail meat [17]. Fat content ranged from 0.42 (M2) to 0.58 (M1), which is higher than reported for dehydrated chicken egg white $(0.04 \%)$, and quail $(0.09 \%)$ and guinea fowl $(0.13 \%)$ albumen [14].

\subsection{Electrophoresis}

Electrophoresis showed the lyophilized quail egg white

Table 1. Moisture, ash, protein and fat contents in quail egg white dried by air convection at two temperatures and two times.

\begin{tabular}{|c|c|c|c|c|}
\hline Components & $\begin{array}{c}\mathrm{M} 1 \\
65^{\circ} \mathrm{C}, 3.5 \mathrm{~h}\end{array}$ & $\begin{array}{c}\mathrm{M2} \\
65^{\circ} \mathrm{C}, 5.0 \mathrm{~h}\end{array}$ & $\begin{array}{c}\text { M3 } \\
70^{\circ} \mathrm{C}, 3.5 \mathrm{~h}\end{array}$ & $\begin{array}{c}\mathrm{M} 4 \\
\mathbf{7 0}{ }^{\circ} \mathrm{C}, \mathbf{5 . 0} \mathrm{h}\end{array}$ \\
\hline Moisture & $(6.36 \pm 0.08)^{\mathrm{b}}$ & $(6.16 \pm 0.02)^{b}$ & $(7.42 \pm 0.03)^{\mathrm{a}}$ & $(6.24 \pm 0.05)^{\mathrm{b}}$ \\
\hline Ash & $6.06 \pm 0.15^{\mathrm{b}}$ & $5.96 \pm 0.22^{\mathrm{c}}$ & $6.63 \pm 0.28^{b}$ & $7.08 \pm 0.09^{\mathrm{a}}$ \\
\hline Protein & $93.96 \pm 0.50^{\mathrm{a}}$ & $93.71 \pm 0.07^{\mathrm{a}}$ & $93.16 \pm 0.24^{\mathrm{a}}$ & $92.56 \pm 0.06^{\mathrm{c}}$ \\
\hline
\end{tabular}


(ML) to exhibit eight bands between 17 and $170 \mathrm{kDa}$ (Figure 1). The four air-dried treatments (M1, M2, M3 and M4) had similar profiles, with the exception of the bands at 55 and 65 , which probably correspond to avidine and G2 or G3 globulins, respectively [18]. The bands at 17 (lysozime), 47 (ovoalbumin) and 74 (ovotransferin) $\mathrm{kDa}$ were similar to those reported for chicken egg white [19].

Overall, the dehydrated quail egg white exhibited a number of similarities to chicken egg white. Ovalbumin (approx. $45 \mathrm{kDa}$ ) is the predominant protein in egg white and represents $54 \%$ of total egg white protein. It is a monomer, globular phosphoglycoprotein with 385 amino acid residues, half of which are hydrophobic. Chicken egg protein is easily denatured by heat, but has a relatively high denaturation temperature of about $84^{\circ} \mathrm{C}$ (Ahmed et al., 2007). In the present study, quail egg white protein did not denature in any of the treatments, suggesting it may also have a high denaturing temperature. The band at $17 \mathrm{kDa}$ is analogous to that reported for lysozyme (approx. $15 \mathrm{kDa}$ ) in chicken egg white [6]. Lysozyme is a glycoprotein representing $3.5 \%$ of chicken egg white, and consists of a single polypeptide chain with 129 amino acids linked by four disulphide bonds. Given their molecular weights in chicken egg white, it is

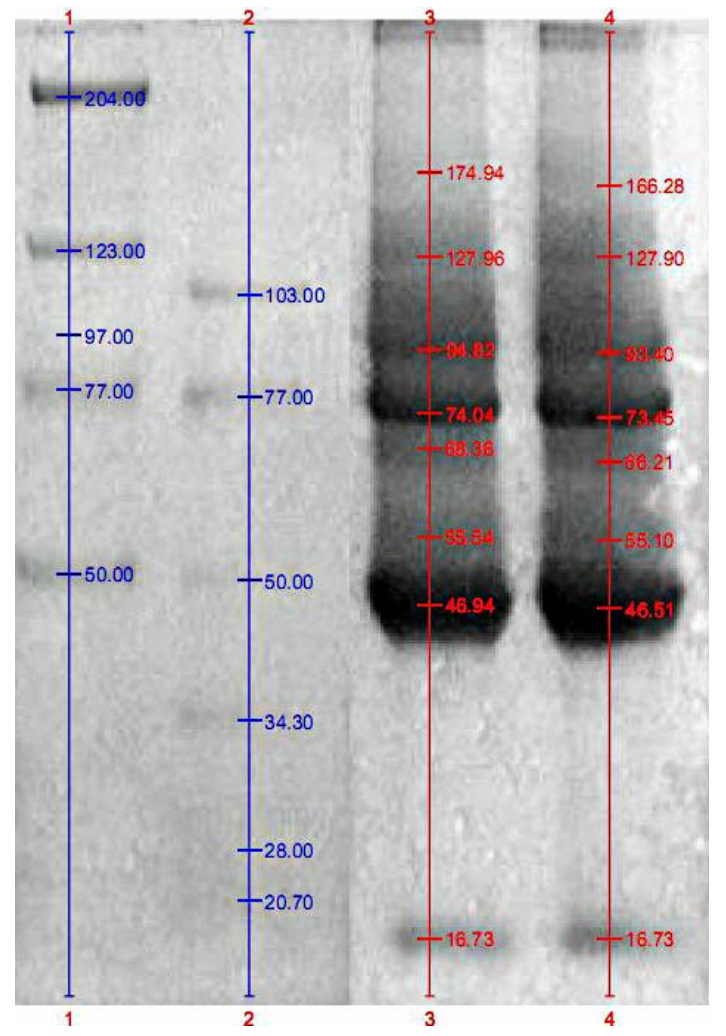

(a) Lyophilized treatment probable that avidin $(53 \mathrm{kDa})$ and conalbumin $(80 \mathrm{kDa})$ are also present in quail egg white. Conalbumin is a glycoprotein accounting for $13 \%$ of chicken egg white. It can bind to metal ions and form a protein-metal complex resistant to denaturation by heat, pressure, proteolithic enzymes and denaturing agents. After drying chicken egg white at $60^{\circ} \mathrm{C}$ for $180 \mathrm{~min}$, Matsuda et al. [19] reported an $80 \mathrm{kDa}$ band corresponding to ovotransferin (conalbumin) while CarraroAlleoni [6] reported that conalbumin's denaturation temperature is $61^{\circ} \mathrm{C}$. Given the above, the $65^{\circ} \mathrm{C}$ dehydration temperature and 3.5 and $5 \mathrm{~h}$ times used in the present study were probably insufficient to denature this protein fraction in quail egg white. In contrast, ovomucin was absent in the studied quail egg white. Ovomucoid is a glycoprotein (approx. $28 \mathrm{kDa}$ ) with trypsin inhibitory activity, and has an important effect on albumin consistency. Low-intensity signals were observed for ovoinhibitor (approx. $49 \mathrm{kDa}$ ), a trypsin and chymotrypsin inhibitor. These were lower in the M1-4 treatments than in ML, perhaps due to partial denaturation.

\subsection{Denaturation Temperature and Enthalpy}

Absorption peaks in the thermograms for M1-4 ranged from $81.16^{\circ} \mathrm{C}$ to $83.85^{\circ} \mathrm{C}$ (Table 2). Denaturation temperatures for the M1, M2 and M3 treatments were similar

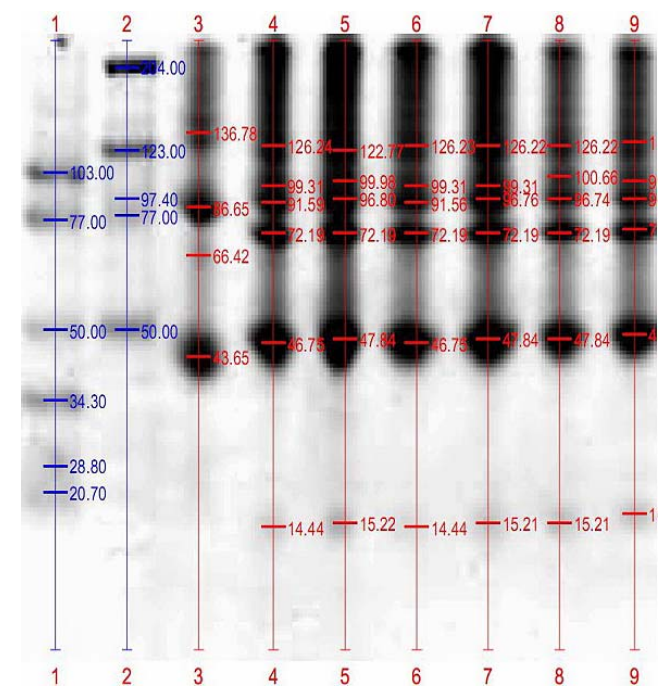

(b) Air convection-dried treatments

Figure 1. Electrophoresis (SDS-PAGE) profiles for dehydrated quail egg white: (a) Standard = 1, 2; ML = 3, 4; (b) Standard $=1,2 ; \mathrm{M1}=3,4 ; \mathrm{M2}=4,5 ; \mathrm{M3}=6,7 ; \mathrm{M} 4=8,9$. 
Table 2. Denaturation temperatures (Td) and enthalpies $(\Delta \mathrm{H})$ of quail egg white dried by air convection $\left(\mathrm{M1}, 6^{\circ} \mathrm{C}\right.$ and $3.5 \mathrm{~h} ; \mathrm{M2}, 65^{\circ} \mathrm{C}$ and $5 \mathrm{~h} ; \mathrm{M3}, 70^{\circ} \mathrm{C}$ and $3.5 \mathrm{~h} ; \mathrm{M4}, 70^{\circ} \mathrm{C}$ and $5 \mathrm{~h}$ ), and lyophilization (ML).

\begin{tabular}{ccc}
\hline Treatment & $\mathbf{T} \boldsymbol{d}\left({ }^{\circ} \mathbf{C}\right)$ & $\Delta \mathbf{H}(\mathbf{J} / \mathbf{g})$ \\
\hline M1 & $83.43 \pm 0.0^{\mathrm{a}}$ & $7.79 \pm 0.02^{\mathrm{b}}$ \\
M2 & $83.85 \pm 0.32^{\mathrm{a}}$ & $7.39 \pm 0.24^{\mathrm{b}}$ \\
M3 & $83.61 \pm 0.24^{\mathrm{a}}$ & $5.51 \pm 0.17^{\mathrm{c}}$ \\
M4 & $82.86 \pm 0.18^{\mathrm{b}}$ & $5.59 \pm 0.05^{\mathrm{c}}$ \\
ML & $81.16 \pm 0.01^{\mathrm{b}}$ & $9.08 \pm 0.03^{\mathrm{a}}$ \\
\hline
\end{tabular}

to the $84.5^{\circ} \mathrm{C}$ reported by Raeker and Johnson [20] for chicken egg ovalbumin suggesting that the denaturation temperatures observed here corresponded to ovalbumin. During storage, ovalbumin is altered to s-ovalbumin, a much more thermo-stable form (denaturation at $92.5^{\circ} \mathrm{C}$ ) than ovalbumin (denaturation at $84^{\circ} \mathrm{C}$ ) [6]. S-ovalbumin has a slightly lighter molecular weight than ovalbumin and its relative proportion in the egg white can increase from $5 \%$ in fresh egg to $81 \%$ after six months of refrigerated storage. The present results suggest that ovalbumin had not converted to s-ovalbumin in the studied treatments. Denaturation temperature was slightly lower in the ML treatment than in the M1-4 treatments, possibly due to conformational changes caused by drying method [21].

Protein denaturation involves alteration of a protein's native form through significant changes in its three-dimensional (3D) conformation produced by movements of different protein domains, a phenomenon which increases molecular entropy. These changes cause a loss in secondary, tertiary and quaternary structure, generating greater interaction between hydrophobic residues and resulting in aggregation of deployed proteins. Heat is one of the most frequently used denaturing methods, and affects stability in the non-covalent interactions of a protein's 3D structure because it lowers molecule enthalpy and breaks the bonds which maintain balance within the structure. In the present study, denaturation enthalpy ranged from $5.51 \mathrm{~J} / \mathrm{g}$ in $\mathrm{M} 3$ to $9.08 \mathrm{~J} / \mathrm{g}$ in $\mathrm{ML}$, meaning the former requires less energy to denature than the latter. Air drying at the studied temperatures may therefore have partially denatured the protein in the quail egg white, whereas drying by lyophilization probably did not [22]. Air-dried quail egg white is therefore a promising ingredient in baked products such as breads and cakes because its denaturation temperature is similar to that of starch gelatinization $\left(85^{\circ} \mathrm{C}-90^{\circ} \mathrm{C}\right)$. Incorporation of this ingredient into baked products would allow an increase in shake viscosity and attainment of maximum volume and texture before and during the baking.

\subsection{Functional Characterization}

\subsubsection{Water-Holding (WHC) and Oil-Holding Capacity (OHC)}

Water-holding capacity was higher in ML $(4.5 \mathrm{~g} / \mathrm{g})$ than in M1-4 (0.90 to $2.95 \mathrm{~g} / \mathrm{g})$. Similar values have been reported for chicken egg white: untreated white $(1.30 \mathrm{~g} / \mathrm{g})$ [22], lyophilized white $(2.58 \mathrm{~g} / \mathrm{g})$ [23]. Differences in WHC between the ML and M1-4 treatments can probably be attributed to heat-induced changes in conformation or partial denaturation. Denaturation led to increased dispersion velocity as the protein molecule unfolded and consequently expanded molecule dimensions. The airdried treatments may have had primarily attractive forces which would force water out of the network matrix and lower WHC. External factors (e.g., stirring velocity, pH, and protein concentration) which can be manipulated during recovery or measurement may also have influenced this property. Food processing and development of new food products require ingredients such as gelling agents which can build up a structural matrix and provide a desirable texture. The dehydrated quail egg white studied here is a promising alternative ingredient in products such as desserts, puddings and reformulated meat products.

Oil-holding capacity was also higher in the ML (1.95 $\mathrm{g} / \mathrm{g})$ than in the M1-4 treatments $(0.92$ to $1.01 \mathrm{~g} / \mathrm{g})$. The higher $\mathrm{OHC}$ in the ML treatment was probably due to a higher nonpolar residue content, which would have provided more contact surface and therefore increased OHC. The OHC values from the M1-4 treatments were lower than reported for lyophilized chicken egg white $(4.22 \mathrm{~g} / \mathrm{g})$ [23]. Based on its OHC values, the ML treatment would be useful in improving structural interactions in food such as flavor retention and improvement of palatability, while the M1-4 treatments would be useful as ingredients in fried products since they would provide a non-greasy sensation.

\subsubsection{Foaming Capacity and Foam Stability}

The ability of the quail egg white proteins to form and stabilize foams was related to their amphiphilic behavior (polar/nonpolar). Foams consist of an aqueous continuous phase and a gaseous disperse phase [24]. Textural properties in foams depend on dispersion of numerous air bubbles and formation of a thin film (lamella) in the liquid-gas interphase. The proteins in the dehydrated quail egg white effectively formed a gaseous disperse phase with each droplet enveloped by a thin, continuous film of protein molecules and each bubble separated by a dense lamella. Foaming capacity in the dehydrated quail egg white was $\mathrm{pH}$-dependent (Figure 2): alkaline $\mathrm{pH}$ resulted in low values, and acid $\mathrm{pH}(\mathrm{pH} 2)$ produced high values. The higher foaming capacity observed at acid $\mathrm{pH}$ was 


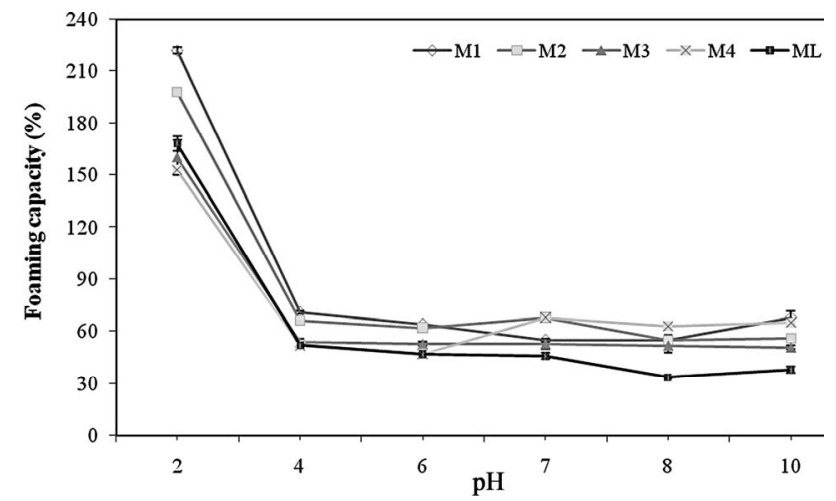

Figure 2. Effect of pH on the foaming capacity (\%) in dehydrated quail egg white: Air convection-dried treatments $\mathrm{M1}\left(65^{\circ} \mathrm{C}, 3.5 \mathrm{~h}\right), \mathrm{M2}\left(65^{\circ} \mathrm{C}, 5 \mathrm{~h}\right), \mathrm{M3}\left(70^{\circ} \mathrm{C}, 3.5 \mathrm{~h}\right)$ and $\mathrm{M} 4$ $\left(70^{\circ} \mathrm{C}, 5 \mathrm{~h}\right)$; Lyophilized treatment, $\mathrm{ML}$.

probably due to an increase in proteinnet charge. This weakens hydrophobic interactions and increases protein flexibility, allowing them to more rapidly spread the air-water interface, encapsulate air particles and increase foam formation. At acid $\mathrm{pH}(2)$, the M1 treatment exhibited a higher $(\mathrm{p}<0.05)$ foaming capacity $(222 \%)$ than M2-4 (153\% - 198\%) and ML (168\%). In M1, this behavior could be explained by a loss of secondary and tertiary structure due to the air-drying treatment $\left(65^{\circ} \mathrm{C}\right.$, $3.5 \mathrm{~h}$ ), which would increase molecule surfactant power. This suggests that a certain sequence of reactions occurred during foam formation with the quail egg white proteins. Energy input would have triggered the process, causing soluble proteins to reach the air-water interface by diffusion, adsorption, concentration and critical surface tension. Polypeptide rearrangement in the interface was oriented by polar mobility, with polar segments drawn to water and non-polar segments drawn to air particles. During interfacial movement, the partially-opened proteins would have formed new intermolecular associations with neighboring molecules, generating the cohesive and continuous films essential to foam formation. The main attractive forces in this process may have been hydrogen bonds, hydrophobic interactions, and electrostatic and van der Waals forces. At alkaline $\mathrm{pH}$ values, foaming capacity in the dehydrated quail egg white treatments was similar to the $60 \%$ reported for dehydrated chicken egg white at $\mathrm{pH} 10$ and a $2 \%$ concentration [16]. Superficial activity in the quail egg white proteins depended on both the hydrophobic/hydrophilic relationship and protein conformation. The high foaming capacity in the M1 treatment was therefore a product of the polypeptide chain stability/flexibility relationship, its adaptability to environmental changes and the distribution patterns of hydrophilic and hydrophobic groups on the protein surface.

Foam stability was lowest in the M1-4 treatments at
pH 2, with losses of 137 (M1), 116 (M2), 103 (M3) and 91\% (M4) from 30 seconds to 120 min (Figure 3). These values reflect the rapid loss of the proteins' capacity to stabilize foam against gravitational and mechanical stress. The foams steadily lost volume after rapid adsorption of the proteins into the interphase, which depended on distribution of hydrophobic and hydrophilic zones on the surface. This loss of volume may have occurred because the protein film formed around each gas bubble was not sufficiently viscous, elastic and resistant to produce gas permeability and inhibit foam coalescence. Therefore, at $\mathrm{pH} 2$ the dehydrated quail egg white in all the treatments was unable to support the weight of the very high foam volume produced. During the same time period $(30 \mathrm{sec}$ to $120 \mathrm{~min}$ ), foam stability was highest in $\mathrm{M} 1(17 \%)$ at $\mathrm{pH}$ 10 , in $\mathrm{M} 2(11 \%)$ at $\mathrm{pH} 8$, in $\mathrm{M} 3(12 \%)$ at $\mathrm{pH} 4$ and in $\mathrm{M} 4$ $(10 \%)$ at $\mathrm{pH}$ 6. The structural components and attractive electrostatic interactions (forces) present under these
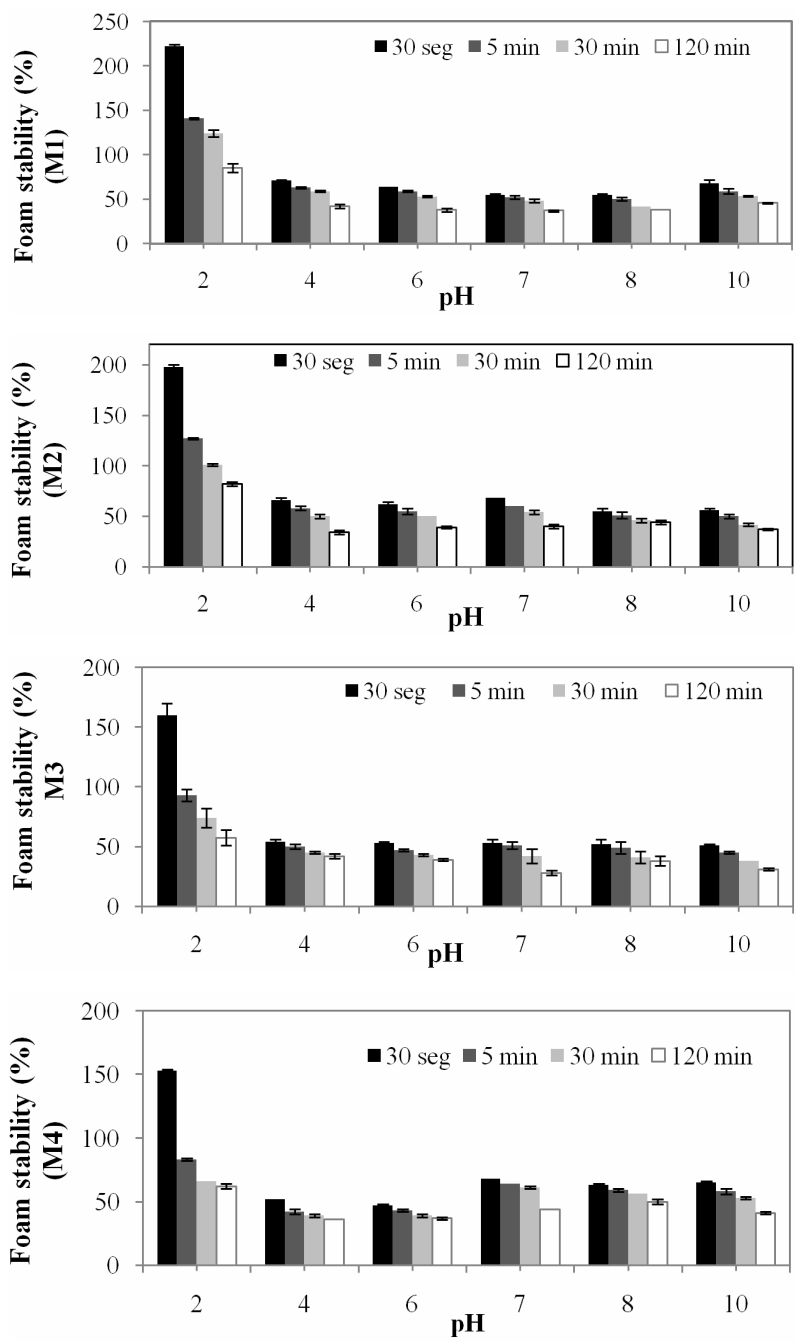

Figure 3. Effect of pH on foam stability (\%) in air convection-dried quail egg white: $\mathrm{M1}\left(65^{\circ} \mathrm{C}, 3.5 \mathrm{~h}\right)$; $\mathrm{M2}\left(65^{\circ} \mathrm{C}, 5 \mathrm{~h}\right)$; $\mathrm{M3}\left(70^{\circ} \mathrm{C}, 3.5 \mathrm{~h}\right)$; $\mathrm{M4}\left(70^{\circ} \mathrm{C}, 5 \mathrm{~h}\right)$. 
conditions enabled the formation of intermolecular associations and improved foaming properties. Non-polar residues intensively contribute to interactive forces at the hydrophobic interface, increasing the surface activity within which hydrophilic residues associated to decrease surface activity, thus improving film quality and foam stability. Foam stability depended on the ability of protein surface activity to improve film elasticity, and was reflected in the balance between forces inside the film and the forces among adjacent bubbles. The high foam stability at alkaline $\mathrm{pH}$ values may also be an artifact of the lower foam volume at these $\mathrm{pH}$ values, which led to lower bubble coalescence.

The proteins which stabilize foams are more stable at their isoelectric point than at other $\mathrm{pH}$ levels. For instance, chicken egg white has good foaming properties at $\mathrm{pH} 8-9$, but at or near its isoelectric $\mathrm{pH}(4-5)$ the reduced presence of repulsion interactions promotes protein-protein interactions and the formation of a viscous film in the interphase which favors foaming capacity and foam stability. In a study of dehydrated chicken egg white, Vani and Zayas [16] reported foam stability values of 52 (30 $\mathrm{min}), 46.6(60 \mathrm{~min}), 42(90 \mathrm{~min})$ and $37.6 \%$ $(120 \mathrm{~min})$ at $\mathrm{pH} 10$ and a $\%$ concentration. Foam stability at $30 \mathrm{~min}$ increased at protein concentrations of $8 \%$ due to a lower liquid flow inside the lamella. Effectively forming a protein capsule that holds air bubbles also requires non-covalent interactions, such as electrostatic and hydrophobic forces, hydrogen bounds, and disulphide linkages. A balance between non-covalent interactions may help to form a cohesive, viscous film, which is required for foam stability. The lower foam stability values observed in the present study were possibly due to electrostatic repulsions. Disulphide linkages reduce protein flexibility, and the change of a thiol group to a disulphide has significant repercussions on functional properties. For example, molecular alterations induced by reduction of disulphide linkages between protein molecules improve film formation in foam and contribute to its stabilization [25]. In another study, Doi et al. [26] found that the essential factor in the formation of stable foam with ovalbumin was not disulphide linkage formation, but network formation by other non-covalent interactions. Disulphide bindingis critical to stabilizing protein structure, constraining molecular unfolding and preventing total exposition of hydrophobic regions, meaning formation of disulphide linkages at the air-water interface may improve foam stability [27]. The proteins in dehydrated egg white encapsulate and retain air, making them useful in improving desirable textural attributes in products such as bread, cookies, meringues, ice creams, and other bakery products during and after processing. However, foaming properties also depend on protein concentration, film thickness, ionic strength, $\mathrm{pH}$, temperature, the presence of other components in food systems, and protein physicochemical properties.

\subsubsection{Emulsifying Activity (EA) and Emulsion Stability (ES)}

Proteins are excellent surfactants in the formulation of food emulsions (oil-water) because their surface is active and favors resistance to coalescence. In the air-dried quail egg white treatments, EA was highest overall at $\mathrm{pH}$ $8(41 \%-46 \%)$, values only slightly lower than that of chicken egg white (53\%) [28]. Overall EA ranges differed $(\mathrm{p}<0.05)$ between treatments across the studied pH levels $(2-10)$ : $\mathrm{M} 1=3 \%$ to $40 \%$; $\mathrm{M} 2=4 \%$ to $42 \%$; $\mathrm{M} 3=3 \%$ to $43 \%$; $\mathrm{M} 4=2 \%$ to $45 \%$; and $\mathrm{ML}=5 \%$ to $15 \%$ (Figure 4). At $\mathrm{pH}$ levels from 2 to 6, M1-4 exhibited EA values between 8 and 23\%. At pH 8 they reached peak EA and then decreased drastically to the lowest levels at $\mathrm{pH} 10$. The ML treatment exhibited EA values $(5 \%-18 \%)$ lower than those of the air-dried treatments at all $\mathrm{pH}$ levels. Conformational stability was a determining factor in the EA behavior of the dehydrated quail egg white as shown by their $\Delta H$ values. Greater instability and emulsifying activity are associated with low $\Delta \mathrm{H}$ values, and the relatively lower values for the M1-4 treatments compared to the ML treatment indicate that the conditions in the air-dried treatments allowed the protein to unfold within the oil-water interface, thus reducing interfacial tension and aiding in emulsion formation. According to Chau et al. [29], the viscosity generated by variation in $\mathrm{pH}$ allows formation of a rigid and elastic protein film appropriate for reducing interfacial tension and producing high EA values at $\mathrm{pH} 8$.

Emulsion stability was pH-dependent in the dehydrated quail egg white (Figure 5). Maximum values were observed at $\mathrm{pH} 2$ and 4 in $\mathrm{M} 1$ (91.81\% and $88.98 \%$, respectively), M3 (97.50\% and $92.16 \%$, respectively) and M4 (96.16\% and $95.74 \%$, respectively). The amphiphilic

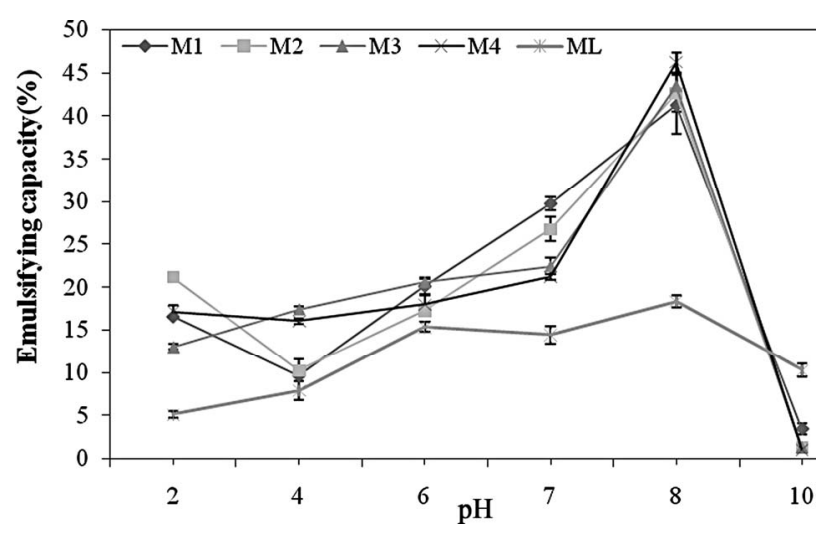

Figure 4. Effect of pH on emulsifying activity (\%) in dehydrated quail egg white: Air convection-dried treatments M1 $\left(65^{\circ} \mathrm{C}, 3.5 \mathrm{~h}\right), \mathrm{M} 2\left(65^{\circ} \mathrm{C}, 5 \mathrm{~h}\right), \mathrm{M3}\left(70^{\circ} \mathrm{C}, 3.5 \mathrm{~h}\right)$ and $\mathrm{M} 4$ $\left(70^{\circ} \mathrm{C}, 5 \mathrm{~h}\right)$; Lyophilized treatment, ML. 


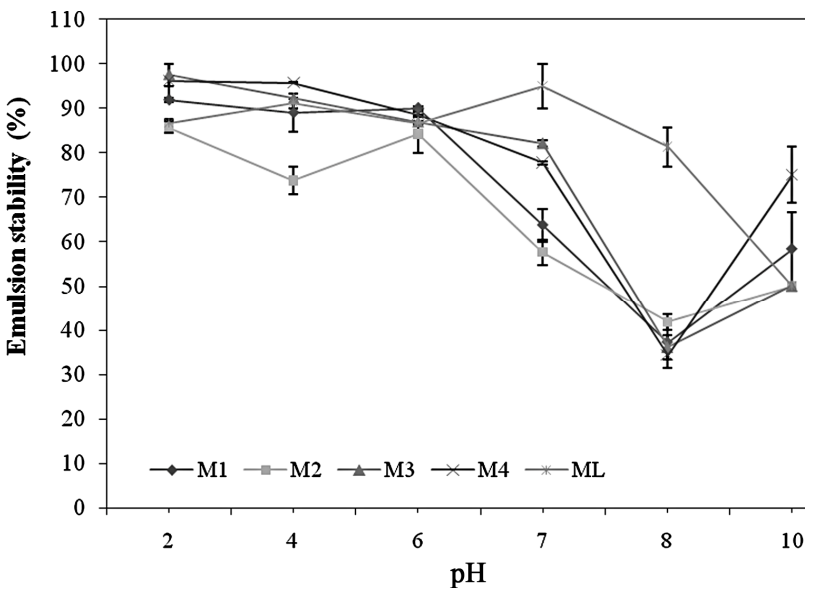

Figure 5. Effect of pH on emulsion stability (\%) in dehydrated quail egg white: Air convection-dried treatments $\mathrm{M1}$ $\left(65^{\circ} \mathrm{C}, 3.5 \mathrm{~h}\right), \mathrm{M} 2\left(65^{\circ} \mathrm{C}, 5 \mathrm{~h}\right), \mathrm{M3}\left(70^{\circ} \mathrm{C}, 3.5 \mathrm{~h}\right)$ and $\mathrm{M} 4$ $\left(70^{\circ} \mathrm{C}, 5 \mathrm{~h}\right)$; Lyophilized treatment, $\mathrm{ML}$.

nature of the proteins in these treatments at these $\mathrm{pH}$ levels probably allowed the oil-water interphase to stabilize because the proteins' free energy was lower in the interphase than in the aqueous phase. These proteins formed a highly viscous film in the interphase which concentrated there and conferred resistance to emulsion particle coalescence. A dramatic decrease in ES occurred at $\mathrm{pH} 8$ $(34 \%$ to $37 \%)$ in the air-dried treatments (M1-4). Emulsifying activity was highest at $\mathrm{pH} 8$, the higher EA suggesting that the protein film could not resist the interfacial tension at the oil-water interphase. Formation of a stable emulsion due to spontaneous and rapid adsorption of the quail egg white proteins into the interphase depended on the distribution of hydrophobic and hydrophilic zones on the surface. When hydrophobic zones are numerous and distributed with enough energy to interact, the probability of adsorption toward the interphase is much greater. The number of peptidic segments in the interphase depends on molecule flexibility. In stable emulsions, the hydrophobic domains are guided toward the oleaginous phase. In general, emulsions stabilized by proteins are affected by the molecular characteristics of these proteins, as well as by intrinsic factors such as $\mathrm{pH}$, ionic force, temperature, low-molecular-weight surfactants, oleaginous phase volume, protein type, oil fusion point, oil incorporation rate and stirrer level. Increased protein flexibility due to denaturation during the drying process allowed the quail egg white proteins to make contact with the oil and water phases, modifying their conformation and allowing them to locate in the interphase. Partial protein denaturation through drying improves emulsifying properties because it increases molecular flexibility and superficial hydrophobicity, thus favoring formation of viscoelastic films in the oil-water interphase.
The present results indicate that convection air-dried quail egg white is probably an effective emulsifier, providing it potential applications in food systems such as sausage, mayonnaise, and seasonings, and any other product in which molecule emulsiondue to increasing temperature occurs before coalescence [10].

\subsection{In Vitro Protein Digestibility}

In vitro protein digestibility for the air-driedtreatments ranged from $81.30 \%$ in $\mathrm{M} 2$ to $83.02 \%$ in $\mathrm{M} 3$ (Table 3). These are similar to the $82.4 \%$ reported for pasteurized chicken egg albumen [30], but higher than the $74.51 \%$ for the lyophilized quail egg white (ML). This higher digestibility in the air-dried treatments may be explained by elimination of anti-nutritional factors and protein denaturation during drying, which would have made the proteins more vulnerable to enzyme action. Lower $\Delta \mathrm{H}$ values $(5.51-7.79 \mathrm{~J} / \mathrm{g})$ in the M1-4 treatments suggest that conformational changes had occurred in the protein molecules, making them more susceptible to enzymatic attachment and therefore producing higher digestibility values. Lack of anti-nutritional factors in the M1-4 treatments is supported by the absence of bands corresponding to anti-nutritional factors such as ovomucoid (trypsin inhibitor) and ovoinhibitor (trypsin and chymotrypsin inhibitor) in the electrophoretic profile. In contrast, a 49 $\mathrm{kDa}$ band corresponding to ovoinhibitor was observed in the ML profile, and is probably the reason for its relatively lower in vitro digestibility.

\section{Conclusion}

Based on the present results, dehydrated quail egg white has potential uses in the food industry. Its protein content is adequate, and convection air drying partially denatured the protein, preserving fractions such as ovalbumin and conalbumin while eliminating anti-nutritional factors such as ovoinhibitor. Denaturation temperature in the dehydrated quail egg white corresponded to ovalbumin, the main protein in egg white. Use of air convection in drying the egg white required less energy to denaturize the protein than lyophilization, making it a promising ingredient in baked products. Heat-induced conformational changes resulted in water-holding capacity values that

Table 3. In vitro digestibility of quailegg white dried by air convection $\left(\mathrm{M} 1,65^{\circ} \mathrm{C}\right.$ and $3.5 \mathrm{~h} ; \mathrm{M} 2,65^{\circ} \mathrm{C}$ and $5 \mathrm{~h} ; \mathrm{M} 3$, $70^{\circ} \mathrm{C}$ and $3.5 \mathrm{~h} ; \mathrm{M4}, 70^{\circ} \mathrm{C}$ and $5 \mathrm{~h}$ ), and lyophilization (ML).

\begin{tabular}{cc}
\hline Treatment & Digestibility (\%) \\
\hline M1 & $82.11 \pm 0.00^{\mathrm{b}}$ \\
M2 & $81.30 \pm 0.09^{\mathrm{c}}$ \\
M3 & $83.02 \pm 0.18^{\mathrm{a}}$ \\
M4 & $82.39 \pm 0.27^{\mathrm{b}}$ \\
ML & $74.51 \pm 0.18^{\mathrm{d}}$ \\
\hline
\end{tabular}


could make dehydrated quail egg white useful in the manufacture of desserts and puddings, while the oilholding capacity values indicate it would provide a nongreasy sensation in fried products. Both $\mathrm{pH}$ and the amphiphilic behavior (polar/nonpolar) of the dehydrated quail egg white proteins affected its foaming behavior, with the highest foaming capacity at acid $\mathrm{pH}$ and the highest foaming stability at alkaline $\mathrm{pH}$. The dehydrated quail egg white effectively formed oil-water emulsions, particularly at $\mathrm{pH} 8$, but its emulsion stability was highest at $\mathrm{pH} 2$, making it useful in food systems such as sausage. Air convection drying increased in vitro digestibility of the quail egg white by eliminating antinutritional factors and exposing its proteins to enzymatic action.

\section{REFERENCES}

[1] N. Vali, "The Japanese Quail: A Review," International Journal of Poultry Science, Vol. 7, No. 9, 2008, pp. 925931. doi:10.3923/ijps.2008.925.931

[2] B. B. Kayang, A. Vignal, M. Inoue-Murayama, M. Miwa, J. L. Monvoisin, S. Ito and F. Minvielle, "A First-Generation Micro Satellite Linkage Map of the Japanese Quail," Animal Genetics, Vol. 35, No. 3, 2004, pp. 195-200. doi:10.1111/j.1365-2052.2004.01135.x

[3] J. K. Amoah and E. A. Martin, "Quail (Coturnix coturnix japonica) Layer Diets Based on Rice Bran and Total or Digestible Amino Acids," Journal of Applied Bioscience, Vol. 26, No. 2, 2010, pp. 1647-1652.

[4] M. González, "Influence of Age on Physical Traits of Japanese Quail (Coturnix coturnix japonica) Eggs," Animal Research, Vol. 44, No. 3, 1995, pp. 307-312. doi:10.1051/animres:19950309

[5] D. Cardoso-Jiménez, S. Rebollar-Rebollar and R. RojoRubio, "Productivity and Profitability of the Quail (Coturnix coturnix japonica) in the Southern Region of the State of Mexico," Mexican Journal of Agronomy, Vol. 12, No. 22, 2008, pp. 517-525.

[6] A. C. Carraro-Alleoni, "Albumen Protein and Functional Properties of Gelation and Foaming," Science Agriculture, Vol. 63, No. 3, 2006, pp. 291-298.

[7] W. Horwitz, "Official Methods of Analysis," 17th Edition, Association of Official Analytical Chemists, Washington DC, 1997.

[8] H. Schagger and G. Von Jagow. "Tricine-Sodium Dodecyl Sulfate-Polyacrylamide Gel Electrophoresis for the Separation of Proteins in the Range from 1 to $100 \mathrm{kDa}$," Analytical Biochemistry, Vol. 166, No. 2, 1987, pp. 368379. doi:10.1016/0003-2697(87)90587-2

[9] E. N. Martínez and M. C. Añon, "Composition and Structural Characterization of Amaranth Protein Isolates. An Electrophoretic and Calorimetric Study," Journal of Agricultural and Food Chemistry, Vol. 44, No. 9, 1996, pp. 2523-2530. doi:10.1021/jf960169p

[10] L. Chel-Guerrero,V. Pérez-Flores, D. Betancur-Ancona and G. Dávila-Ortiz, "Functional Properties of Flours and Protein Isolates from Phaseolus lunatus and Canavalia ensiformis Seeds," Journal of Agricultural and Food Chemistry, Vol. 50, No. 3, 2002, pp. 584-591. doi:10.1021/jf010778j

[11] H. Hsu, D. Vavak, L. Satterlee and G. Miller, "A Multi Enzyme Technique for Estimating Protein Digestibility," Journal of Food Science, Vol. 42, No. 5, 1977, pp. 12691279. doi:10.1111/j.1365-2621.1977.tb14476.x

[12] D. Montgomery, "Diseño y Análisis de Experimentos," Limusa-Wiley, México DF, 2004.

[13] I. O. Dudusola, "Comparative Evaluation of Internal and External Qualities of Eggs from Quail and Guinea Fowl," International Research Journal of Plant Science, Vol. 1, No. 5, pp. 112-115.

[14] C. V. Morr, B. German, J. E. Kinsella, J. M. Regenstein, J. P. Van Buren, A. Kilara, B. A. Lewis and M. E. Mangino, "A Collaborative Study to Develop a Standardized Food Protein Solubility Procedure," Journal of Food Science, Vol. 50, No. 6, 1985, pp. 1715-1718. doi:10.1111/j.1365-2621.1985.tb10572.x

[15] A. Baniel, A. Fains and Y. Popineau, "Foaming Properties of Egg Albumen with a Bubbling Apparatus Compared with Whipping," Journal of Food Science, Vol. 62, No. 2, 1997, pp. 377-381. doi:10.1111/j.1365-2621.1997.tb04005.x

[16] B. Vani and J. F. Zayas, "Foaming Properties of Selected Plant and Animal Proteins," Journal of Food Science, Vol. 60, No. 5, 1995, pp. 1025-1028. doi:10.1111/j.1365-2621.1995.tb06285.x

[17] I. Boni, H. Nurul and I. Noryati, "Comparison of Meat Quality Characteristics between Young and Spent Quails," International Food Research Journal, Vol. 17, No. 3, 2010, pp. 661-666.

[18] W. I. Stadelman and O. J. Cotterill, "Foaming," In: Egg Science \& Technology, Food Product Press, Haworth Press Inc., Binghamton, 1994, pp. 418-434.

[19] T. Matsuda, K. Watanabe and Y. Sato, "Heat-Induced Aggregation of Egg White Proteins as Studied by Vertical Flat-Sheet Polyacrylamide Gel Electrophoresis," Journal of Food Science, Vol. 46, No. 6, 1981, pp. 1829-1834. doi:10.1111/j.1365-2621.1981.tb04498.x

[20] M. Ö. Raeker and L. A. Johnson, "Thermal and Functional Properties of Bovine Blood Plasma and Egg White Proteins," Journal of Food Science, Vol. 60, No. 4, 1995, pp. 685-690. doi:10.1111/j.1365-2621.1995.tb06206.x

[21] C. Myers, "Study of Thermodynamics and Kinetics of Protein Stability by Thermal Analysis," In: Thermal Analysis of Foods, Elsevier Science Publishing Co., Inc., New York, 1990, pp. 16-50.

[22] J. C. Cheftel, J. L. Cuq and D. Lorient, "Proteínas Alimentarias," Acribia, Zaragoza, 1989, pp. 49-175.

[23] R. J. Kanterewicz, B. E. De Elizalde, A. M. R. Pilosof and G. B. Bartholomai, "Water-Oil Absorption Index (WOAI): A Simple Method for Predicting the Emulsifying Capacity of Food Proteins," Journal of Food Science, Vol. 52, No. 5, 1987, pp. 1381-1383. doi:10.1111/j.1365-2621.1987.tb14087.x

[24] L. Du, A. Prokop and R. D. Tanner, "Effect of Denaturation by Preheating on the Foam Fractionation Behavior of 
Ovalbumin," Journal of Colloid and Interface Science, Vol. 248, No. 2, 2002, pp. 487-492.

doi:10.1006/jcis.2001.8163

[25] J. B. German and L. Phillips, "Protein Interactions in Foams: Protein-Gas Phase Interactions," In: Protein Functionality in Food Systems, Marcel Dekker, Inc., New York, 1994, pp. 181-208.

[26] E. Doi and N. Kitabatake, "Structure and Functionality of Egg Proteins," In: Food Proteins and Their Applications, Marcel Dekker, Inc., New York, 1997, pp. 325-340.

[27] E. Li-Chan and S. Nakai, "Raman Spectroscopy Study of Thermally and/or Dithiothreitol Induced Gelation of Lisozyme," Journal of Agricultural and Food Chemistry, Vol. 39, No. 7, 1991, pp. 1238-1245.

doi:10.1021/jf00007a009
[28] M. Ahmenda, W. Prinyawiwatkul and R. Rao, "Solubilized Wheat Protein Isolate: Functional Properties and Potential Food Applications," Journal of Agricultural and Food Chemistry, Vol. 47, No. 4, 1999, pp. 1340-1345. doi:10.1021/jf981098s

[29] C. F. Chau, K. Cheung and Y. S. Wong, "Functional Properties of Protein Concentrates from Three Chinese Indigenous Legume Seeds," Journal of Agricultural and Food Chemistry, Vol. 45, No. 11, 1997, pp. 2500-2503. doi: $10.1021 / \mathrm{jf9} 90047 \mathrm{c}$

[30] C. R. Hank, M. E. Kunkel, P. L. Dawson, J. C. Acton and F. B. Wardlaw, "The Effect of the Shell Egg Pasteurization on the Protein Quality of Albumen," Poultry Science, Vol. 80, No. 6, 2001, pp. 821-824. 